\title{
Kształtowanie nawyków prozdrowotnych u dzieci w młodszym wieku szkolnym w kontekście edukacji sustensywnej
}

\author{
Shaping Health Habits of Early School Children in The Context of Sustainable Education
}

\author{
Joanna Waszczuk, Helena Konowaluk-Nikitin, Ewa Pawłowicz-Sosnowska \\ Państwowa Szkoła Wyższa im. Papieża Jana Pawła Il w Białej Podlaskiej \\ ORCID: JW https://orcid.org/0000-0001-8823-7691; HK-N https://orcid.org/0000-0002-5128-3982; \\ EP-S https://orcid.org/0000-0001-9391-7886•awaszczuk@op.pl \\ Zgłoszono: 27.02.2021; zrecenzowano: 19.04.2021; zaakceptowano do druku: 21.04.2021
}

Streszczenie: We współczesnej literaturze przedmiotu koncepcje zrównoważonego rozwoju od strony teoretycznej są dość dobrze opracowane, dostrzega się jednak potrzebę zbadania zastosowania tych idei w praktyce. Ważne wydaje się zatem budowanie strategii działań zwłaszcza w odniesieniu do sfery świadomościowej. Kształtowanie społecznej świadomości zrównoważonego rozwoju warunkowane jest kształtowaniem postawy prozdrowotnej dzieci już w młodszym wieku szkolnym. Dlatego celem podjętych badań, których wyniki są przedstawione w artykule, było poznanie poziomu nawyków prozdrowotnych, jaki osiągnęły dzieci w wieku wczesnoszkolnym, jako elementu edukacji sustensywnej. Analiza uzyskanych wyników badań pozwoliła odpowiedzieć na kluczowe pytanie problemowe, w jaki sposób kształtuje się postawa prozdrowotna dzieci w wieku wczesnoszkolnym w kontekście zrównoważonego rozwoju z udziałem oddziaływań rodziców i nauczycieli? Wyniki badań pokazały wysoki poziom nawyków prozdrowotnych dzieci, co w pewnym stopniu wskazuje na potrzebę utrzymania strategii działań edukacji sustensywnej poprzez realizację zadań w aspekcie współdziałania środowiska szkolnego i rodzinnego, a także na potrzebę kontynuacji badań z wymienionego obszaru.

Słowa kluczowe: dziecko, nawyki prozdrowotne, zrównoważony rozwój, edukacja zdrowotna, edukacja sustensywna, wychowanie

\begin{abstract}
In the current literature on the subject the theoretical concepts of sustainable development are fairly well documented, there is however a need to research the applications of those ideas in practice. It seems important then to build strategies of actions especially concerning the realm of consciousness. A necessary condition for shaping social consciousness of sustainable development is shaping pro-health attitude of children as soon as in early school. That is why, the goal of the study, whose results have been presented in this article, was to inspect the level of pro-health habits achieved by early school children in the course of sustainable education. An analysis of the results allowed to answer the key problem question: "How is pro-health attitude of early school children shaped in the context of sustainable development, with the influences of parents and teachers?" The results of the study showed a high level of pro-health habits in children, which to some degree points towards a need to keep up the strategy of actions of sustainable education by executing tasks in the aspect of cooperation of school and family environments, and also a need to continue research in the aforementioned territory.
\end{abstract}

Keywords: child, health habits, sustainable development, health education, sustainable education, rearing 


\section{Wprowadzenie}

Coraz częściej słyszy się w środkach przekazu, z ust nauczycieli, lekarzy czy rodziców o problemach zdrowia dzieci i młodzieży w naszym kraju i poza nim. Aktualność tej kwestii jest znacząca nie tylko dla mieszkańców Polski, lecz także dla wszystkich mieszkańców planety. W dobie technologii informacyjnych są tworzone różnorodne urządzenia elektroniczne, które mają człowieka wyręczać w przeróżnych sytuacjach, zastępować jego wysiłek w różnych codziennych czynnościach. Zjawisko to jednak niesie za sobą również zagrożenia, gdyż sprzyja pogorszeniu stanu zdrowia tak dorosłych, jak i dzieci. Jednym z ważniejszych i globalnych problemów współczesnego świata stało się zachowanie i wzmocnienie zdrowia dzieci (Kaczor-Szkodny et al. 2018, 77).

Obserwuje się wzrost liczby osłabionych fizycznie dzieci, wzrost patologii i schorzeń dziecięcych. Próchnica zębów dotyka już około 70\% dzieci w wieku szkolnym. Co trzecie dziecko przychodzące do szkoły ma osłabiony wzrok. Ponadto z przyczyn obiektywnych zmniejsza się zaangażowanie siłowe aparatu ruchu u dzieci, gdyż coraz rzadziej uczestniczą one w grach i zabawach ruchowych. Powoduje to narastanie problemu otyłości. Niektórzy zaś rodzice zbytnio inwestują w rozwój umysłowy swoich pociech (Nackiewicz i Baran 2018, 81).

Pogłębiające się zanieczyszczenie środowiska naturalnego i ciągłe stresy źle odbijają się na zdrowiu dzieci. Ich odporność spada, przez co często chorują. Właśnie dlatego priorytetowym zadaniem rodziców, pedagogów i przedstawicieli wszystkich instytucji społecznych jest ochrona zdrowia dzieci, wychowanie dorastającego pokolenia w lepszej kondycji psychofizycznej (Kowalczyk 2015,111 ) oraz zapewnienie wysokiej jakości życia. Angus Cambpell uznawany za prekursora badań nad jakością życia, definiuje ją jako doświadczenie życia przejawiające się w poziomie satysfakcji życiowej oraz poczuciu szczęścia (Campbell 1976).

Wiek przedszkolny i wczesnoszkolny jawi się jako okres wrażliwy na kształtowanie korzystnych nawyków, które - w łączności z nauczaniem dzieci sposobów zachowania i doskonalenia zdrowia - powinny doprowadzić do pozytywnych wyników (Klim-Klimaszewska 2011, 67).

Edukacja zdrowotna jest definiowana jako „całożyciowy proces uczenia się ludzi jak żyć, aby zachować i doskonalić zdrowie własne i innych" (Woynarowska 2013, 143). Takie ujęcie jest ważnym elementem podstawy programowej, w której podkreślono, że celem jest kształtowanie u uczniów nawyku dbałości o zdrowie własne i innych ludzi, a także umiejętności tworzenia środowiska sprzyjającego zdrowiu. W szkołach, jak podaje Ewa Szadzińska, przygotowuje się uczniów do zdobywania umiejętności niezbędnych do poprawy stanu środowiska oraz tworzenia nowych wzorców zachowań, kształtowania postaw, przekonań jednostek, grup i społeczeństw (Szadzińska 2014, 30). Sprzyjać temu mają również założenia zrównoważonego rozwoju (sustainable development), w Polsce zwanego też czasem „ekorozwojem”, „trwałym rozwojem”, albo „rozwojem sustensywnym” (Klimska 2014).

Jak wiadomo, zdrowie kształtuje się pod wpływem różnych czynników wewnętrznych i zewnętrznych, do których zalicza się: stan organizmu, dobrostan człowieka psychiczny i społeczny. Szadzińska podkreśla, że czynniki środowiskowe mają dominujące znaczenie w kształtowaniu się zdrowia dziecka (Szadzińska 2014, 37). W związku z tym szkoły za priorytetowy kierunek swojej działalności wychowawczej powinny przyjąć prowadzenie działań, które będą skierowane bezpośrednio na polepszenie, wzmocnienie, zachowanie i wzbogacenie zdrowia dzieci, nauczycieli i rodziców, poprzez tworzenie w placówkach edukacyjno-wychowawczych wszystkich niezbędnych warunków sanitarno-higienicznych i psychologiczno-pedagogicznych (Woynarowska 2013, 147).

Problem potrzeby kształtowania w dzieciach wiedzy o własnym zdrowiu jest pracą systematyczną, celową i długofalową. Wyrobienie w dziecku dobrej, troskliwej 
i świadomej postawy wobec własnego ciała znajduje się w puli głównych zadań pedagogiczno-wychowawczych. Pracę pielęgnowania własnego zdrowia należy zaczynać od formowania odruchów higieny osobistej.

Ważnym warunkiem dbania o higienę osobistą jest nabywanie przez dzieci zespołu przyzwyczajeń autopielęgnacyjnych. Przykładowo, dziecko, które myje zęby rano i wieczorem, w sytuacji niemożliwości dokonania tej czynności czuje się niekomfortowo. Natomiast dziecko nieprzyzwyczajone do korzystania ze szczoteczki do zębów nie odczuje dyskomfortu z tego powodu. W celu rozwiązania takiego problemu w edukacji wczesnoszkolnej wykorzystuje się różnorodne formy organizacji aktywności fizycznej dzieci (Piech 2011, 14).

Uczniowie jednak spędzają czas nie tylko w szkole, lecz także w rodzinie. Dlatego konieczne jest również zaangażowanie rodziców do realizacji filozofii zrównoważonego rozwoju w aspekcie wdrożenia zasad zdrowego stylu życia oraz rozszerzenie kompetencji pedagogicznych rodziców w wychowaniu zdrowego dziecka poprzez zaangażowanie ich we wspólną aktywność. Jednocześnie rozwijać trzeba kulturę pedagogiczną rodziców na drodze ich edukowania w temacie fizjologii zdrowego organizmu, zwiększenia jego witalności i odporności na choroby z wykorzystaniem aktywności ruchowej, ćwiczeń oddechowych i hartowania się (Charzewska i Wolnicka 2013, 7).

W kształtowaniu postawy prozdrowotnej dzieci w wieku wczesnoszkolnym w kontekście zrównoważonego rozwoju z udziałem oddziaływań rodziców oraz w kreowaniu higienicznego środowiska życia, zakładającego zapewnienie czynników niezbędnych do powstawania u dzieci postawy dbałości o zdrowie - uwzględnia się efekt utrzymanej informacji zwrotnej. Nie otrzymując szybkich wyników działań korzystnych dla swego zdrowia, dzieci częstokroć mogą stracić zainteresowanie nimi i bezmyślnie wykonywać automatyczne działania. Efekt zatrzymanego związku zwrotnego jest jedną $\mathrm{z}$ wiodących przyczyn negatywnych zachowań i postaw dzieci. Istnieje uniwersalna metoda, która jednakowo sprzyja wzmocnieniu zdrowia dziecka, jak i prawidłowemu wychowaniu. Najzwyczajniej należy zachować porządek dnia nie tylko w szkole, lecz także w domu. Należy pilnować rozkładu: posiłków, snu, spacerów i procedur higieny o stałych porach doby. Taka stałość utworzy sprzyjające i skuteczniejsze warunki zdrowotne dla organizmu. Wychowane w warunkach codziennego zachowania rozkładu dnia dzieci zazwyczaj nie miewają kaprysów czy buntu. Dzieci mają zakodowane wyobrażenie o tym, że na wszystko jest właściwy czas, miejsce, miara. Rozkład dnia jest nazywany uniwersalnym środkiem, ponieważ łączy w sobie najważniejsze wymogi pedagogiki i higieny, które wpływają prozdrowotnie. Z myślą o tym warto prowadzić rozległą pracę edukacyjną z dziećmi i ich rodzicami. Oprócz rozkładu dnia dziecko potrzebuje podstawowej wiedzy o swoim organizmie i ciele, o potrzebie kształtowania zdrowego stylu życia.

Postawa dziecka wobec własnego zdrowia i zdrowia innych bazuje na potrzebie bycia zdrowym, prowadzeniu zdrowego stylu życia, całościowej samoocenie własnego zdrowia. Dzieci nie mają wrodzonej potrzeby stosowania zdrowego stylu życia. Ta świadoma potrzeba powinna przyświecać rodzicom, nauczycielom i całemu społeczeństwu. Niewątpliwie w każdym dziecku jest wielkie pragnienie, aby szybciej urosnąć, stać się silnym, nie różnić się od zdrowszych kolegów, a jeszcze lepiej, by być lepszym od nich. Bazując na tych emocjach, warto kształtować w dziecku nawyk „wsłuchania się” w swoje zdrowie, swój organizm, potrzebę rozumienia i opisu własnego stanu fizycznego i psychicznego oraz niezwłocznie podejmować właściwe działania z zakresu edukacji sustensywnej.

\section{Założenia metodologiczne badań}

Przeprowadzone badania mieszczą się w obszarze pedagogiki wczesnoszkolnej w zakresie edukacji zdrowotnej. Celem badań 
było poznanie poziomu nawyków prozdrowotnych, jaki osiągnęły dzieci w wieku wczesnoszkolnym, jako elementu edukacji sustensywnej.

Badania miały charakter pilotażowy, stanowiły jedynie fragment szerszego zakresu badawczego, dotyczącego analizy nawyków prozdrowotnych wśród dzieci w wieku wczesnoszkolnym.

Cel badań był istotnym czynnikiem wyboru metod ilościowych, które polegają na „ilościowym opisie i analizie faktów, zjawisk i procesów" (Łobocki 2006, 59). Zaletą metod ilościowych jest to, że wyniki można przedstawić w formie różnych zestawień, w przypadku niniejszych badań poznania opinii rodziców na temat nawyków prozdrowotnych ich dzieci i opracowania wyników jako wskaźników procentowych (Łobocki 2006, 91).W niniejszych badaniach do poznania opinii dzieci w wieku wczesnoszkolnym zastosowano Test 1 dla rodziców pt. „Czy zdrowo żyje Twoje dziecko?” oraz Test 2 dla uczniów - „Dlaczego tak postępujesz?". Test został zapożyczony od białoruskich badaczy zajmujących się problematyką zdrowego stylu życia i nawyków zdrowotnych u dzieci w wieku wczesnoszkolnym (Аолматова 2015). Kwestionariusz testu zawiera 8 pytań oraz przyporządkowane im odpowiedzi zamknięte.

Badania przeprowadzono w kwietniumaju 2020 r. wśród dzieci w wieku wczesnoszkolnym. Każde dziecko wypełniało test samodzielnie. Ze względu na ogłoszoną w kraju epidemię badania zostały przeprowadzone $\mathrm{z}$ wykorzystaniem platformy Teams w trybie online.

Ogółem w badaniu wzięło udział 42 dzieci. Wśród badanych $12 \%$ dzieci uczęszczało do klasy I, 44\% do klasy II oraz tyle samo - 44\% - do klasy III. Spośród badanych dzieci 79\% zdeklarowało posiadanie rodzeństwa, natomiast $21 \%$ to jedynaki. W trakcie badań ustalono również miejsce zamieszkania badanych. Dla 83,2\% była to wieś, w mieście od 50 tys. do 150 tys. żyło $12 \%$ respondentów, natomiast w mieście do 50 tys. zamieszkiwało $4,8 \%$ ankietowanych dzieci.

\section{Wyniki badań własnych}

Zebrany materiał badawczy został poddany szczegółowej analizie ilościowej. W początkowej fazie skupiono się na danych dotyczących nawyków prozdrowotnych dziecka w sferze higieny osobistej, do których należy m.in. higiena rąk, nóg oraz mycie zębów.

Możliwość osobistego ustosunkowania się do obowiązujących w danej grupie społecznej norm buduje poczucie podmiotowości oraz rozwija świadomość dziecka. Odwołując się do powyższego stwierdzenia, zapytano dziecko: Dlaczego myjesz ręce? Procentowy rozkład odpowiedzi przedstawiono w tabeli 1.

Uzyskane odpowiedzi wskazują, iż dla 74,4\% respondentów powodem higieny rąk jest osobista troska o czystość. Natomiast $24 \%$ badanych wskazało, iż trzeba myć ręce, a 2,4\% stwierdziło, że ze strony rodziców doświadcza przymusu mycia rąk.

Mycie rąk i nóg są niewątpliwie wskaźnikami zachowań prozdrowotnych dziecka. Jak zatem wygląda kwestia higieny nóg? Wśród zebranych odpowiedzi - na pytanie: Po co myjesz nogi? - zdecydowana większość (88\%) odpowiedziała, iż nie lubi, kiedy nogi są brudne, 9,6\% myje nogi, bo tak trzeba, a $(2,4 \%)$ myje pod przymusem dorosłych.

Analiza kolejnego pytania dotyczyła higieny zębów. Starano się ustalić powody tego typu zachowań wśród badanej populacji dzieci w wieku wczesnoszkolnym. Z zebranych danych wynika, iż 53\% ankietowanych myje zęby, ponieważ niemyte zęby prowadzą do powstania chorób. Kolejne miejsce zajmuje mycie zębów, ponieważ tak trzeba. Odpowiedziało w ten sposób 33\% badanych. W 14\% przypadków dzieci myją zęby, ponieważ są do tego zmuszane przez rodziców.

Założenia przeprowadzonych badań odwołują się również do wskazania roli aktywności fizycznej jako komponentu zdrowego stylu życia zarówno dzieci, jak i dorosłych. Można w związku z tym powiedzieć, iż gimnastyka poranna, spacery, uczestnictwo w zajęciach sportowych czy tanecznych są zalecane w procesie kształtowania nawyków 
prozdrowotnych dziecka. Jak zatem w praktyce wyglacda ta kwestia? Zebrane odpowiedzi przedstawia tabela 2.

Respondenci wskazali w 90,5\% odpowiedzi, iż należy uczestniczyć w zajęciach sportowych lub tanecznych, natomiast 9,5\% ankietowanych nie wyraziło pozytywnej opinii o wskazanej formie aktywności fizycznej.

Określeniu posiadanych nawyków prozdrowotnych służy analiza zebranych odpowiedzi na pytanie: Dlaczego uprawiasz gimnastykę poranną? Dzieci biorące udział w badaniu w 34\% przypadków odpowiedziały, iż potrzebuje tego ich zdrowie. W 33\% przypadków badani podejmują się uprawiania gimnastyki, ponieważ dorośli tak chcą oraz podobnie $33 \%$ wskazań - bo tak trzeba.

W kolejnym pytaniu podjęto próbę ustalenia: Ile czasu powinno się spacerować? Odnotowano odpowiedzi, iż 76,4\% badanych uznało, że dziecko powinno spacerować codziennie $1,5^{-2}$ godzin, natomiast $14 \%$ - codziennie, ale nie mniej niż godzinę. Czasami w wolne dni spaceruje 9,6\% badanych dzieci.

Nawyki prozdrowotne dziecka kształtowane są przez podejmowane zabiegi higieniczne, różne formy aktywności fizycznej, zdrowe odżywianie się. Czy oglądanie telewizji sprzyja formowaniu zdrowego stylu życia? O to właśnie zapytano respondentów. Wyniki umieszczono w tabeli 3.

Analiza zebranego materiału pozwoliła dowiedzieć się, iż w opinii $83,2 \%$ badanych dzieci należy oglądać telewizję nie dłużej niż 1,5 godziny dziennie z przerwami. Można korzystać z telewizora, ile się chce to $12 \%$ udzielonych odpowiedzi, natomiast dla $4,8 \%$ respondentów uznało oglądanie telewizji przez 3 godziny dziennie jako czas optymalny.

Kolejne pytanie wśród analizowanych brzmiało: kiedy należy chodzić spać? Zebrane odpowiedzi prezentuje tabela 4 .

Respondenci w 83,2\% przypadków wskazali, iż należy chodzić spać pomiędzy godziną 20.30 a 21.00. Wśród badanych 17,8\% uważa, iż należy chodzić spać po godzinie 21.00, natomiast po godzinie 22.00 nie odnotowano żadnej odpowiedzi.
Tab. 1. Powody mycia rąk przez dziecko

\begin{tabular}{lll}
\hline Lp. & \multicolumn{1}{c}{ Dlaczego myjesz ręce? } & $\%$ \\
\hline 1. & Dorośli mnie do tego zmuszają & 2,4 \\
\hline 2. & Bo tak trzeba & 24 \\
\hline 3. & $\begin{array}{l}\text { Nie lubię, jak mam brudne ręce i dużo } \\
\text { zarazków }\end{array}$ & 74,4 \\
\hline \multicolumn{2}{l}{ Ogółem } & 100
\end{tabular}

Źródło: badania własne

Tab. 2. Opinia badanych odnośnie do aktywności fizycznej

\begin{tabular}{llc}
\hline Lp. & $\begin{array}{l}\text { Jak uważasz, czy należy chodzić do } \\
\text { sekcji sportowej lub tanecznej? }\end{array}$ & $\%$ \\
\hline 1. & Tak & 90,5 \\
\hline 2. & Nie & 9,5 \\
\hline Ogółem & 100 \\
\hline
\end{tabular}

Źródło: badania własne

Tab. 3. Pogląd na oglądanie telewizji

\begin{tabular}{llc}
\hline $\begin{array}{l}\text { Lp. } \\
\text { telewizję? }\end{array}$ & $\%$ \\
\hline 1. & $\begin{array}{l}\text { Nie dłużej, niż 1,5 godziny dziennie } \\
\text { z przerwami }\end{array}$ & 83,2 \\
\hline 2. & Ponad 3 godziny & 4,8 \\
\hline 3. & lle się chce & 12 \\
\hline Ogółem & 100 \\
\hline
\end{tabular}

Źródło: badania własne

Tab. 4. Opinia na temat godziny snu

\begin{tabular}{llc}
\hline Lp. & $\begin{array}{l}\text { Jak uważasz, kiedy należy chodzić } \\
\text { spać? }\end{array}$ & $\%$ \\
\hline 1. & W godzinach 20.30-21.00 & 83,2 \\
\hline 2. & Po godzinie 21.00 & 17,8 \\
\hline 3. & Po godzinie 22.00 & - \\
\hline Ogółem & & 100 \\
\hline
\end{tabular}

Źródło: badania własne

Tab. 5. Jedzenie warzyw przez dzieci w opinii rodziców

\begin{tabular}{llc}
\hline Lp. & Jak często dziecko je warzywa? & $\%$ \\
\hline 1. & Prawie codziennie & 12,1 \\
\hline 2. & Prawie nigdy & 17,4 \\
\hline 3. & Czasami & 70,5 \\
\hline Ogółem & & 100 \\
\hline
\end{tabular}

Źródło: badania własne 
Oprócz poruszanych w powyższych analizach obszarów świadomości dziecka w aspekcie higieny osobistej oraz aktywności fizycznej, niepokojące wyniki otrzymano w sferze percepcji spożywania zdrowej żywności przez badane dzieci w wieku wczesnoszkolnym w odpowiedzi rodziców. Według respondentów tylko 12,1\% dzieci spożywa warzywa prawie codziennie, a aż 70,5\% spożywa je tylko czasami, gdy rodzice do tego zmotywują, a nawet przymuszą. Niestety $17,4 \%$ dzieci odmawia jedzenia warzyw, bo nie lubią ich smaku i tylko czasami udaje się rodzicom namówić je na zjedzenie zdrowego, smacznego warzywa. Zebrane dane przedstawiono $\mathrm{w}$ tabeli 5 .

W związku z tym pojawia się pilna potrzeba edukacji rodziców w kierunku promowania wśród ich dzieci zdrowej żywności. Szczególnie dotyczy to przedstawiania korzyści zdrowotnych i walorów smakowych warzyw spożywanych w codziennej diecie. Jednocześnie ważne jest wskazanie rodzicom zasad konsekwentnego działania, w tym powstrzymanie dzieci od spożywania dużej ilości słodyczy.

\section{Podsumowanie}

Wyniki przeprowadzonych badań sprzyjają kilku refleksjom. Przede wszystkim można powiedzieć, że w badanej grupie dzieci posiadają wysoki poziom świadomości zachowań prozdrowotnych w sferze higieny osobistej oraz aktywności fizycznej, a tylko w sferze zdrowego odżywiania się dzieci w codziennej diecie nadal bardziej wolą słodycze niż owoce i warzywa.

Sytuacja wychowawcza rodziny silnie warunkuje występowanie nawyków w kierunku zdrowia fizycznego, jak i psychicznego.

Postawa nauczycieli również wzmacnia nawyki prozdrowotne dzieci/uczniów.

Niestety, niejednokrotnie zapomina się o utrzymaniu trwałości osiągniętych rezultatów będących podstawą do kształtowania dalszych zmian w nawykach zdrowotnych dzieci.

Zadaniem edukacji zdrowotnej jest przygotowanie dziecka do wzięcia większej odpowiedzialności za swoje zdrowie oraz nakłonienie rodziców do podjęcia działań, które przyczynią się zarówno do utrzymania, jak i poprawy stanu zdrowia ich dzieci. Praktyka szkolna w kształtowaniu nawyków prozdrowotnych nie zawsze idzie w parze z zachowaniami zdrowotnymi środowiska rodzinnego. Edukacja przyszłości w aspekcie zrównoważonego rozwoju w dużej mierze zależy od rodziców jako kreatorów przestrzeni zdrowotnej.

Zdrowie fizyczne i psychiczne stanowią podstawową wartość, tak więc wdrażanie idei edukacji sustensywnej od najmłodszych lat życia dziecka zapewni mu wszechstronny, zrównoważony rozwój. Odpowiedzialność za to zadanie niewątpliwie leży w gestii środowiska rodzinnego dziecka, ale szczególnie - środowiska szkolnego.

Proponujemy, aby realizacja zagadnień z zakresu edukacji zdrowotnej i ekologicznej - jako elementu edukacji sustensywnej - obejmowała szczególnie aktywność środowiska szkolnego np. w formie organizowanych eventów ekologicznych, akcji prozdrowotnych i ekologicznych, współpracy ze środowiskiem lokalnym dziecka, np. z Lasami Państwowymi, organizacjami czy stowarzyszeniami działającymi na rzecz zdrowia i zdrowego środowiska.

\section{Bibliografia}

Campbell, Angus. 1976. „Subjective measures of wellbeing". American Psychologist, 31(2): 117.

Charzewska, Jadwiga, i Katarzyna Wolnicka. 2013. Szkoła i przedszkole przyjazne żywieniu i aktywności fizycznej. Poradnik dla nauczycieli. Warszawa: Instytut Żywności i Żywienia.

Аомматова, Аидия. 2015. Мотивация ЗОЖ Тесты. Правимьно $и$ ты живёшь? https://nsportal. ru. Dostęp 3.09.2018. [Dolmatova, Lidiya. 2015. Motivatsiya ZOZH Testy. Pravil'no li ty zhivosh'?]

Kaczor-Szkodny, Paulina, Teresa B. Kulik, Magdalena Florek-Łuszczki, i Lech Panasiuk. 2018. „Edukacja zdrowotna w kontekście szkół promujących zdrowie." W Rola $i$ wyzwania nauk medycznych, red. Monika Maciąg i Kamil Maciąg, 77-88. Lublin: TYGIEL. 
Klim-Klimaszewska, Anna. 2011. Pedagogika przedszkolna. Warszawa: Wydawnictwo Naukowe PWN.

Klimska, Agnieszka. 2014. „Współczesne modele edukacji do zrównoważonego rozwoju". W Przyszłość edukacji-edukacja przyszłości, red. Wojciech Welskop, 9-15. Łódź: Wydawnictwo Naukowe Wyższej Szkoły Biznesu i Nauk o Zdrowiu.

Kowalczyk, Anna. 2015. „Rola nauczycieli i rodziców $\mathrm{w}$ organizacji czasu wolnego dzieci w wieku wczesnoszkolnym." Edukacja Elementarna w Teorii i Praktyce 1: 95-113.

Łobocki, Mieczysław. 2006. Metody i techniki badań pedagogicznych. Kraków: Oficyna Wydawnicza Impuls.
Nackiewicz, Jolanta, i Zbigniew Baran. 2018. "Otyłość jako globalna «epidemia» XXI wieku." Prace Naukowe Wyższej Szkoty Zarzadzania i Przedsiębiorczości 46(2): 77-90.

Piech, Anna. 2011. „Rodzina naturalnym środowiskiem wychowawczym". W Rodzinne $i$ instytucjonalne środowiska opiekuńczowychowawcze, red. Dorota Wosik-Kawala, 13-32. Lublin: UMCS.

Szadzińska, Ewa. 2014. Dydaktyczne "tropy" zrównoważonego rozwoju w edukacji. Kraków: Oficyna Wydawnicza Impuls.

Woynarowska, Barbara. 2013. Edukacja zdrowotna. Warszawa: Wydawnictwo Naukowe PWN. 